\title{
The Role of Policy Fundamentals in Fostering Economic Growth in Developing Countries
}

\author{
Minh Quang Dao \\ Eastern Illinois University, Charleston, USA \\ Email:mqdao@eiu.edu
}

Received October 10, 2013; revised November 8, 2013; accepted November 15, 2013

Copyright (C) 2013 Minh Quang Dao. This is an open access article distributed under the Creative Commons Attribution License, which permits unrestricted use, distribution, and reproduction in any medium, provided the original work is properly cited.

\begin{abstract}
This paper examines the role of policy fundamentals in fostering economic growth in developing countries. Based on data from the World Bank for the 2000-2011 period and a sample of sixty-two developing economies we find that the growth rate of per capita GDP is dependent on a country's investments in human capital as measured by the share of the public sector in total health expenditure and by the relative size of public education in the government's budget, on an enabling business environment as measured by two Doing Business indicators, namely the cost of starting a business as a percent of per capita income and the number of days required to enforce contracts, and by the share of losses due to theft, robbery, vandalism, and arson in sales as reported in the enterprise surveys, on the depth of the credit information index and the share of domestic credit provided by the banking sector in the GDP, on the initial level of per capita GDP, and on the share of the net inflow of foreign direct investment (FDI) in the GDP. We observe that the coefficient estimates of two explanatory variables, namely, the share of the public sector in total health expenditure and by the relative size of public education in the government's budget, do not have their expected sign, possibly to the collinearity between these variables and the cost of starting a business as a percent of per capita income as well as with the initial level of per capita GDP. In addition, the share of the public sector in total health expenditure is not significant via using the t-test. We suspect that this is also due to the collinearity between this variable and the cost of starting a business as a percent of per capita income as well as with the initial level of per capita GDP. Statistical results of such empirical examination will assist governments in developing countries and focus on appropriate policy fundamentals in order to foster economic growth.
\end{abstract}

Keywords: Doing Business Indicators; Investments in Human Capital; Per Capita GDP Growth; Developing Countries

\section{Introduction}

This study empirically examines the role of policy fundamentals in fostering economic growth. According to the 2013 World Development Report: Jobs, while the key engine of job creation is the private sector, being responsible for 90 percent of all jobs in the developing economies, governments also play a crucial role in ensuring that the conditions are present for robust private sector-led economic growth and in easing the constraints which prevent the private sector from creating good jobs for growth [1]. The Report identifies the first stage in the approach to assisting government to meet these goals as policy fundamentals which include, among other things, financial access, stability, and efficiency, investments in human capital and a business environment conducive to investment and hence to growth.
This paper attempts to estimate the role of these policy fundamentals in fostering economic growth. Based on data from the World Bank for the 2000-2011 period and a sample of sixty-two ${ }^{1}$ developing economies we find that the growth rate of per capita GDP is dependent on a country's investments in human capital as measured by the share of the public sector in total health expenditure and by the relative size of public education in the gov-

\footnotetext{
${ }^{1}$ The sample consists of the following countries: Algeria, Argentina, Armenia, Azerbaijan, Bangladesh, Belarus, Benin, Botswana, Bulgaria, Burundi, Cameroon, Chad, Colombia, Costa Rica, Côte d'Ivoire, Czech Republic, Egypt, Estonia, Ethiopia, The Gambia, Georgia, Ghana, Guinea, Hungary, Indonesia, Jamaica, Kenya, Lao PDR, Latvia, Lebanon, Lesotho, Liberia, Lithuania, Madagascar, Malawi, Malaysia, Mali, Mauritania, Mauritius, Moldova, Mongolia, Morocco, Nepal, Pakistan, Peru, Philippines, Poland, Portugal, Senegal, Serbia, Sierra Leone, Slovak Republic, Slovenia, South Africa, Sri Lanka, Swaziland, Tanzania, Thailand, Togo, Uganda, Vietnam, Republic of Yemen.
} 
ernment's budget, on an enabling business environment as measured by two Doing Business indicators, namely the cost of starting a business as a percent of per capita income and the number of days required to enforce contracts, and by the share of losses due to theft, robbery, vandalism, and arson in sales as reported in the enterprise surveys, on the depth of the credit information index and the share of domestic credit provided by the banking sector in the GDP, on the initial level of per capita GDP, and on the share of the net inflow of foreign direct investment (FDI) in the GDP. We observe that the coefficient estimates of two explanatory variables, namely, the share of the public sector in total health expenditure and by the relative size of public education in the government's budget, do not have their expected sign, possibly to the collinearity between these variables and the cost of starting a business as a percent of per capita income as well as with the initial level of per capita GDP. In addition, the share of the public sector in total health expenditure is not significant via using the t-test. We suspect that this is also due to the collinearity between this variable and the cost of starting a business as a percent of per capita income as well as with the initial level of per capita GDP. We also note that neither the share of gross capital formation in the GDP nor the degree of trade openness as measured by the share of exports and imports in the GDP explains cross-country variations in per capita GDP growth rates. Statistical results of such empirical examination will assist governments in developing countries and focus on appropriate policy fundamentals in order to foster economic growth.

This paper is organized as follows. In the next section, a selected review of the economic literature on the effect of institutions and business environment on economic growth is discussed. This is followed by the formulation of a statistical model to be estimated. Theoretical underpinnings for the inclusion of explanatory variables are presented in this section. Statistical results are reported in the subsequent section. A final section gives concluding remarks as well as policy recommendations.

\section{Selected Review of the Literature}

Much of the research on identifying the key determinants of economic growth in developing countries recently points to differences in underlying public policies and institutions as the main factor. Empirical studies have used a myriad of variables as proxies for institutions, which include measures of the risk of expropriation, the limits to the power of the executive branch and the power of the rule of law (see, for example, Hall and Jones [2] and Acemoglu, Johnson and Robinson [3]. Frankel and Romer, on the other hand, identify as a primary factor of economic development as measured by per capita income specific economic policies such as the extent to which a country is open to international trade, while Gallup, Sachs and Mellinger attribute development to geographical determinants such as differences in climate and coastal access $[4,5]$.

Using instrumental variable regressions, Rodrik, Subramanian and Trebbi evaluate the main competing explanations, namely good institutions and good economic policies as well as geography and show that institutions measured as a variable defining the strength of the rule of law are dominant relative to both economic policy measured as the degree of openness to international trade and geography in terms of explaining cross-country variations in per capita income levels [6]. Glaeser, La Porta, Lopez-de-Silanes, and Shleifer, however, revisit the issue of whether political institutions lead to economic growth or growth and human capital accumulation cause to better institutions [7]. They argue that most indicators of institutional quality are conceptually unsuitable for being used in explaining growth and also find flaw in some of the instrumental variable techniques used in the literature. Their basic OLS results suggest that education levels are a more basic source of growth rather than institutions. Djankov, McLiesh, and Ramalho use objective measures of business regulations in 135 countries find a positive relationship between better regulations as measured by the Doing Business indicator and economic growth [8].

More recently, Gillanders and Whelan argue that the emphasis on the primacy of legal and political institutions may be misleading and argue that business-friendly economic policies as proxied by the World Bank's Doing Business indicator are the main factor contributing to cross-country differences in per capita income levels [9]. They find that the Doing Business rank is dominant over a range of measures of legal and political institutional quality in terms of explaining variations in per capita income. They also find the rank to be statistically significant in explaining cross-country differences in economic growth while observing that the significant role of educational attainment as found by previous studies is not supported when the rank is included in their growth regressions.

Building upon the first stage in the approach to help governments in developing countries meet the objectives of both insuring that the conditions are present for robust private sector-led growth and easing the constraints that prevent the private sector from creating good jobs for development, namely policy fundamentals that include investments in human capital, financial access, stability, and efficiency, and an enabling business environment, we next specify a statistical model relating these policy fundamentals to the growth of per capita income. Empirical results are presented in a subsequent section. The final section gives concluding remarks as well as policy 
implications.

\section{The Statistical Model}

Following Djankov, McLiesh, and Ramalho [8] and Gillanders and Whelan [9], we use the World Bank's Doing Business indicators as proxies for business-friendly economic policies (also referred to as objective measures of business regulations). According to the World Bank, in addition to macroeconomic stability, other factors that shape daily economic activity such as the rule of law, regulations, and institutional arrangements also determine the economic health of a country. The Doing Business indicators can be helpful to policymakers in under- standing the business environment in a country. A contribution of this study is that we also include the World Bank Enterprise Surveys as proxies for the business environment. These Surveys compile data at the firm level in order to benchmark the business environment of various economies and evaluate how productivity and job creation are affected by business environment constraints. In some countries, crime, theft, and disorder impose costs on business and society. This in turn will have a negative impact on economic growth.

To estimate the impact of policy fundamentals on economic growth we specify the following statistical mo$\operatorname{del}^{2}$ :

$$
\begin{aligned}
y_{p c}= & \beta_{0}+\beta_{1} \text { PubHealth }+\beta_{2} \text { PubEd }+\beta_{3} \text { StartCost }+\beta_{4} \text { CntrctDays }+\beta_{5} \text { CredDeep } \\
(+) & (+) \quad(-)
\end{aligned}
$$

where $y_{p c}=$ Average annual growth rate of per capita GDP, 2000-11.

PubHealth $=$ Public sector share of total health expenditure, in percent, in 2010.

PubEd = Public expenditure on education as a percentage of total government expenditure, in 2010.

StartCost $=$ Cost of starting a business as a percentage of per capita income, in June 2011.

CredDeep $=$ Depth of credit information index, from 0 (low) to 6 (high), in 2010.

CredBank $=$ Domestic credit provided by banking sector as a percentage of GDP, in 2010.

Crime $=$ Losses due to theft, robbery, vandalism, and arson as a percentage of sales, various survey years.

$P G D P 00=$ Per capita GDP at purchaser prices, in dollars, in 2000.

NetFDI $=$ Share of net inflows of foreign direct investment in GDP, in percent, in 2011.

$I / Y=$ Share of gross capital formation in GDP, in percent, in 2010.

Openness $=$ Share of exports and imports of goods and services in GDP, in percent, in 2010.

We use the 2000-2011 per capita GDP growth rate at market prices based on constant local currency for $y_{p c}$. We expect the coefficient estimates for the two investments in human capital variables to have a positive sign. On the other hand, since the cost of starting a business is normalized as a percentage of gross national income (GNI) per capita and includes all official fees and fees for legal or professional services if they are required by law, the coefficient estimate for this variable is expected to have a negative sign.
The depth of credit information index measures rules affecting the scope, accessibility, and quality of information available through public or private credit registries. Since higher values indicate the availability of more credit information, we expect the coefficient estimate for this variable to have a positive sign. The domestic credit provided by the banking sector as a share of GDP measures banking sector depth and financial development in terms of size. The banking sector includes monetary authorities, deposit money banks, and other banking institutions for which data are available. We thus expect the coefficient estimate for this variable to also have a positive sign.

Crime, theft, and disorder impose costs on businesses and society. As the estimated losses from those causes that happened on establishments' premises as a percentage of annual sales increase, we expect them to have a negative effect on per capita GDP growth. To capture the tendency for poor countries to grow faster than rich countries (termed $\beta$-convergence) we include the initial (2000) level of real per capita GDP and expect the coefficient estimate for this variable to have a negative sign as well.

There is much controversy over the benefits and costs

\footnotetext{
${ }^{2}$ In an earlier model, we included all seven sets of Doing Business indicators: starting a business, registering property, dealing with construction permits, getting electricity, enforcing contracts, protecting investors, and resolving insolvency. We also included all 11 dimensions of the business environment as gathered by the World Bank Enterprise Surveys, covering regulation, corruption, crime, informality, finance, infrastructure, and trade. We only found two Doing Business indicators and one dimension of the Surveys to be statistically significant and thus only included them in the statistical model. These results are available from the author upon request.
} 
of foreign direct investment in the development economics literature. On the other hand, foreign direct investment (as well as foreign assistance) is typically seen as a means of filling gaps between the domestic supplies of savings, foreign exchange, government revenue, and human capital skills and the desired level of these inputs needed to achieve growth targets. On the other hand, while multinational corporations provide capital, they may also reduce saving and investment rates by stifling competition through exclusive production agreements with host governments, failing to invest much of their profits, generating incomes for domestic groups with lower propensities to save, and inhibiting the expansion of native firms that might supply them with intermediate products by instead importing these products from overseas affiliates. In addition, while the foreign exchange position of the recipient country is initially improved by foreign direct investment, in the long run its impact may be to lower foreign exchange earnings on both current and capital accounts. Also, even though foreign direct investment does contribute to government revenue in the form of corporate taxes, its contribution is lessened due to liberal tax concessions, the practice of transfer pricing, excessive investment allowances, public subsidies in disguise, and tariff protection provided by the recipient government. Finally, the dominance of local markets by multinational corporations may result in inhibiting the development of local sources of management and entrepreneurial skills by stifling the growth of native entrepreneurial ability. In light of the pros and cons of the effect of foreign direct investment, the real assessment of this effect becomes an empirical question. It follows then that the sign of the coefficient estimate for this variable cannot be assigned $a$ priori.

Using the rather traditional approach of the aggregate production function one can show that the share of gross capital formation in the GDP exerts a positive impact on per capita GDP growth. Finally, trade is an important factor stimulating economic growth as it expands a country's consumption capabilities, enlarges world output, and provides access to scarce resources and global markets for products without which poor countries would not be able to grow. We thus use the share of exports and imports in the GDP as a measure of a country's degree of trade openness and expect the coefficient estimate for this variable to have a positive sign.

Data for all variables are from the 2012 and the 2013 World Bank Indicators [10,11].

\section{Empirical Results}

Table 1 gives least-squares estimates of regression coefficients in Equation (1) for a sample of sixty-two developing economies. We observe that eight of the explanatory variables are statistically significant at the 10 per-
Table 1. Dependent variable: Per capita GDP growth rate.

\begin{tabular}{ccc}
\hline & Coefficient Estimates & t-Statistics \\
\hline Intercept & 7.104 & 3.674 \\
PubHealth & -0.026 & $-1.430^{*}$ \\
PubEd & -0.110 & $-2.156^{* *}$ \\
StartCost & -0.010 & $-1.578^{*}$ \\
CntrctDays & -0.002 & $-2.195^{* *}$ \\
CredDeep & 0.446 & $2.926^{* *}$ \\
CredBank & -0.012 & $-1.788^{* *}$ \\
Crime & -0.366 & $-1.353^{*}$ \\
PGDP00 & -0.0002 & $-1.479^{*}$ \\
Net FDI & 0.020 & 0.863 \\
I/Y & 0.025 & 0.737 \\
Openness & 0.005 & 0.696 \\
\hline
\end{tabular}

Adjusted $\mathrm{R}^{2}=0.461 .{ }^{*}$ Significant at the 10 percent level. ${ }^{* *}$ Significant at the 5 percent level.

cent or lower level and eight coefficient estimates do have their anticipated sign. The goodness of fit of the model is quite good as indicated by the value of 0.461 of the adjusted coefficient of determination.

All else equal, a one-percentage point increase in the share of the cost of starting a business in per capita GDP is expected to lead to a 0.01 percentage point decline in per capita GDP growth. On the other hand, a one-day increase in the time required to enforce contracts is expected to cause per capita GDP growth rate to decrease by 0.002 percentage point, ceteris paribus. As the depth of credit information index increases by one point, we would expect per capita GDP growth rate to increase by 0.45 percentage point while a one percentage point increase in the share of losses due to theft, robbery, vandalism, and arson in sales is expected to result in a 0.37 percentage point decline in per capita GDP growth rate. This latter growth rate is expected to decrease by 0.02 percentage point for every one-hundred dollar increase in the 2000 per capita GDP level. This result is consistent with $\beta$-convergence, even though its effect is rather weak.

A backward elimination stepwise method was applied to arrive at a revised model, the regression results of which are reported in Table 2. We note that the goodness of fit of the model to the data is better as indicated by the higher value of 0.471 of the adjusted coefficient of determination.

We observe that qualitatively the results are much the same except that net foreign direct investment inflows as a percent of GDP is now statistically significant, while the share of the public sector in total health expenditure is now not significant using the t-test. We suspect that this is due to the collinearity between this variable bet- 
ween this variable and the cost of starting a business as a percent of per capita income as well as with the initial level of per capita GDP.

Ceteris paribus, as a one percentage point increase in the share of losses due to theft, robbery, vandalism, and arson in sales is expected to result in a 0.43 percentage point decline in per capita GDP growth rate, while a one percentage point increase in the share of net foreign direct investment inflows results in an expected increase of 0.03 percentage point in the per capita GDP growth rate.

We suspect that due to the extent of the multicollinearity problem among explanatory variables, one of them are not statistically significant based on t-tests while the coefficient estimates on a few others do not have their anticipated sign. We report this extent in Table 3 in the form of a sample correlation coefficient matrix.

\section{Conclusions}

In this paper we use an econometric model to examine the effect of policy fundamentals on economic growth by using data from a sample of sixty-two developing countries. From the statistical results we are able to draw the following conclusions:

1). Within the set of sixty-two developing economies used in this study, investments in human capital have a significant impact on economic growth. Governments in these countries need to continue to devote an adequate share of their budget to public education and health in order to facilitate economic growth.
2). Governments in developing countries need to provide an enabling business environment to encourage further growth. Specifically, this may be done through a reduction in the cost of starting a business and in the time required to enforce contracts. In addition, they need to make an effort to lessen the incidence of property crimes such as theft, robbery, vandalism, and arson.

$3)$. Regression results also show the importance of financial access, stability, and efficiency in promoting economic growth. Governments in developing countries need to strengthen the rules that affect the scope, accessibility, and quality of information available through public credit registries.

Table 2. Dependent variable: Per capita GDP growth rate (revised model).

\begin{tabular}{ccc}
\hline & Coefficient Estimates & t-Statistics \\
\hline Intercept & 8.237 & 5.392 \\
PubHealth & -0.019 & -1.171 \\
PubEd & -0.114 & $-2.296^{* *}$ \\
StartCost & -0.011 & $-1.726^{* *}$ \\
CntrctDays & -0.002 & $-2.977^{* *}$ \\
CredDeep & 0.433 & $2.884^{* *}$ \\
CredBank & -0.011 & $-1.769^{* *}$ \\
Crime & -0.430 & $-1.679^{*}$ \\
PGDP00 & -0.0002 & $-1.719^{*}$ \\
Net FDI & 0.031 & $1.585^{*}$ \\
\hline
\end{tabular}

Adjusted $\mathrm{R}^{2}=0.471 .{ }^{*}$ Significant at the 10 percent level. ${ }^{* *}$ Significant at the 5 percent level.

Table 3. Sample correlation coefficient matrix.

\begin{tabular}{|c|c|c|c|c|c|c|c|c|c|}
\hline & PubHealth & PubEd & StartCost & CntrctDays & CredDeep & CredBank & Crime & $P G D P 00$ & Net FDI \\
\hline PubHealth & 1 & & & & & & & & \\
\hline \multirow[t]{2}{*}{ PubEd } & -0.026 & 1 & & & & & & & \\
\hline & -0.199 & & & & & & & & \\
\hline \multirow[t]{2}{*}{ StartCost } & -0.398 & 0.232 & 1 & & & & & & \\
\hline & -3.358 & 1.845 & & & & & & & \\
\hline \multirow[t]{2}{*}{ CntrctDays } & -0.051 & -0.102 & 0.059 & 1 & & & & & \\
\hline & -0.395 & -0.792 & 0.454 & & & & & & \\
\hline \multirow[t]{2}{*}{ CredDeep } & 0.211 & -0.290 & -0.572 & -0.135 & 1 & & & & \\
\hline & 1.669 & -2.347 & -5.406 & -1.057 & & & & & \\
\hline \multirow[t]{2}{*}{ CredBank } & 0.104 & -0.177 & -0.256 & 0.047 & 0.374 & 1 & & & \\
\hline & 0.812 & -1.391 & -2.054 & 0.361 & 3.119 & & & & \\
\hline \multirow[t]{2}{*}{ Crime } & -0.137 & 0.152 & 0.501 & 0.037 & -0.410 & -0.225 & 1 & & \\
\hline & -1.067 & 1.189 & 4.481 & 0.283 & -3.484 & -1.786 & & & \\
\hline \multirow[t]{2}{*}{$P G D P 00$} & 0.475 & -0.341 & -0.361 & 0.065 & 0.400 & 0.521 & -0.310 & 1 & \\
\hline & 4.182 & -2.814 & -2.996 & 0.502 & 3.382 & 4.733 & -2.530 & & \\
\hline \multirow[t]{2}{*}{ Net FDI } & -0.150 & -0.151 & 0.071 & 0.090 & -0.115 & 0.156 & 0.119 & -0.132 & 1 \\
\hline & -1.178 & -1.182 & 0.551 & 0.698 & -0.900 & 1.224 & 0.931 & -1.030 & \\
\hline
\end{tabular}

Note: Bold t-statistics imply statistical significance at the 10 percent or lower level. 
4). There is empirical evidence that poor countries do tend to grow faster than rich countries even though this effect seems rather weak. Foreign direct investment is also shown to have a positive impact on economic growth, suggesting that its benefits tend to outweigh its costs, at least for the sample of sixty-two countries used in this study.

\section{Acknowledgments}

I would like to thank Thi Minh Chi Le for her support during the completion of this paper.

\section{REFERENCES}

[1] World Bank, "World Development Report 2013: Jobs," Oxford University Press, New York, 2013.

[2] R. E. Hall and C. I. Jones, "Why Do Some Countries Produce So Much More Output per Worker than Others?" Quarterly Journal of Economics, Vol. 114, No. 1, 1999, pp. 83-116. http://dx.doi.org/10.1162/003355399555954

[3] D. Acemoglu, S. Johnson and J. A. Robinson, "The Colonial Origins of Comparative Development: An Empirical Investigation," American Economic Review, Vol. 91 No. 5, 2001, pp. 1369-1401. http://dx.doi.org/10.1257/aer.91.5.1369

[4] J. A. Frankel and D. Romer, "Does Trade Cause Growth?"
American Economic Review, Vol. 89, No. 3, 1999, pp. 379-399. http://dx.doi.org/10.1257/aer.89.3.379

[5] J. L. Gallup, J. D. Sachs and A. Mellinger, "Geography and Economic Development," CID Working Papers No. 1, Center for International Development at Harvard University, Cambridge, 1999.

[6] D. Rodrik, A. Subramanian and F. Trebbi, "Institutions Rule: The Primacy of Institutions over Geography and Integration in Economic Development," Journal of Economic Growth, Vol. 9, No. 2, 2004, pp. 131-165. http://dx.doi.org/10.1023/B:JOEG.0000031425.72248.85

[7] E. L. Glaeser, R. La Porta, F. Lopez-de-Silanes and A. Shleifer, "Do Institutions Cause Growth?" NBER Working Paper No. 10568, Cambridge, 2004.

[8] S. Djankov, C. McLiesh and R. M. Ramalho, "Regulation and Growth," Economics Letters, Vol. 92, No. 3, 2006, pp. 395-401. http://dx.doi.org/10.1016/j.econlet.2006.03.021

[9] R. Gillanders and K.Whelan, "Open for Business? Institutions, Business Environment and Economic Development," University College Dublin School of Economics Working Papers No. 20104, Dublin, 2010.

[10] World Bank, "World Development Indicators," Oxford University Press, New York, 2012.

[11] World Bank, "World Development Indicators," Oxford University Press, New York, 2013. 